\title{
The Triple Helix Frame Contributes to Strategic Innovation in Nearshore Wind Park Ecosystems
}

\author{
Tove Brink \\ Associated Professor, Department of Sociology, Environmental and \\ Business Economics, University of Southern Denmark, Denmark \\ tbr@sam.sdu.dk
}

\begin{abstract}
This research shows how port authorities in a triple helix context can contribute to strategic innovation with reduction of Levelized Cost of Energy in nearshore wind park ecosystems. The empirical qualitative case study was conducted from September 2017 to June 2018 with a port and a nearshore wind park owner and a logistic business actor operating on land and one operating at sea. Individual interviews and three joint network meetings provided data for the research.

The findings reveal that port authorities in triple helix contexts can contribute to strategic innovation through use of the cross-disciplinary trinity of 'organization', 'business model innovation' and 'financial cash flow' to address value creation on project ecosystem level. The findings are summarized in a model for overview on the shift in interest and the basic understanding of flow. It is shown that the triple helix discussions provide a meaningful frame to achieve strategic innovation for competitive advantage of renewable wind energy ecosystem.
\end{abstract}

\section{Keywords}

strategic innovation - ecosystems - renewable energy - offshore wind parks 


\title{
Arabic
}

مسزارع الرياحة افوذج المراوح الثلثة في البتكار الستراتيجي في النظمة البيئية المحيطة

\author{
Tove Brink
}

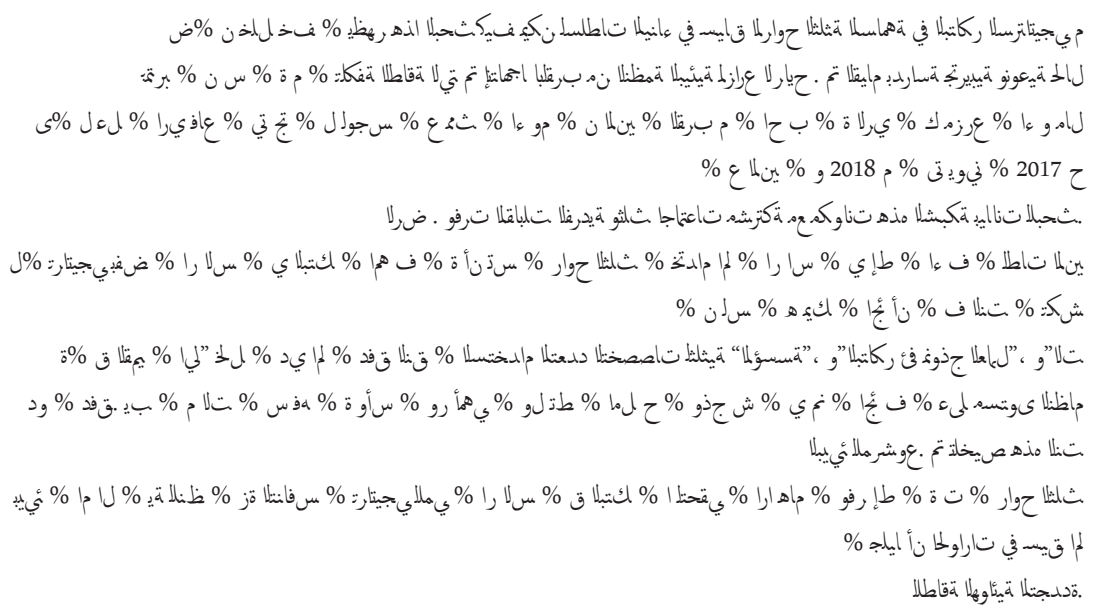

\section{Chinese}

\section{三螺旋框架对近岸风电场生态体系战略创新的贡 献}

\author{
Tove Brink
}

摘要

这项研究显示：在三螺旋情境下港务局如何通过降低近岸风电场生态系统 的平准化能源成本为战略创新做贡献。在 2017 年 9 月至 2018 年 6 月, 我们进行了 实证定性案例研究, 研究对象包括一个港口、一个近岸风电场所有者、一 个陆上物流业务参与者和一个海上运营商。个人访谈和三次联合网络会议 为本研究提供了数据。 
研究结果表明, 在三螺旋情境下港务局可利用跨学科三位一体的 “组 织”、“商业模式创新” 和 “财务现金流” 来实现在项目生态体系层面上 的价值创造, 促进战略创新。我们用一个模型概括了研究结果, 总体上包 括利益转移和对流动的基本理解。我们看到三螺旋讨论为实现可再生风能 生态体系竞争优势的战略创新提供了一个有意义的框架。

\title{
French
}

\section{Contribution du cadre de la triple hélice à l'innovation stratégique dans les écosystèmes de parcs éoliens côtiers}

\author{
Tove Brink
}

\section{Résumé}

Cette étude montre comment, dans un contexte de triple hélice, les autorités portuaires peuvent contribuer à l'innovation stratégique en réduisant le coût-plafond de l'énergie dans les écosystèmes de parcs éoliens côtiers. Létude de cas qualitative et empirique a été menée de septembre 2017 à juin 2018 sur un propriétaire d'un port et d'un parc éolien côtier, un acteur du secteur de la logistique opérant sur terre et un autre en mer. Des entretiens individuels et trois réunions conjointes de mise en réseau ont permis de collecter les données de recherche.

Les résultats révèlent que, dans les contextes de triple hélice, les autorités portuaires peuvent contribuer à l'innovation stratégique en utilisant la trinité interdisciplinaire « organisation », « innovation de modèle d'affaires » et «flux de trésorerie » pour créer de la valeur au niveau de l'écosystème du projet. Les résultats sont résumés sous un modèle offrant une vue d'ensemble du changement d'intérêt et de la compréhension basique du flux. Il est démontré que les discussions sur la triple hélice offrent un cadre significatif à l'écosystème de l'énergie éolienne renouvelable pour réaliser une innovation stratégique avec un avantage concurrentiel. 


\title{
Portuguese
}

\section{A abordagem da Hélice Tríplice contribui para inovações estratégicas no nearshore de ecossistemas de parques eólicos}

\author{
Tove Brink
}

\section{Resumo}

A presente pesquisa mostra como autoridades portuárias no contexto da Hélice Tríplice podem contribuir para inovações estratégicas com a redução do Custo de Nivelamento de Energia no nearshore de ecossistemas de parques eólicos. O estudo de caso empírico e qualitativo foi conduzido de setembro de 2017 a junho de 2018 com o proprietário de um porto e de um nearshore de parques eólicos, um agente operando na logística em terra e outro na logística no mar. Entrevistas individuais e três reuniões conjuntas forneceram os dados para a pesquisa.

Os resultados revelam que autoridades portuárias no contexto da Hélice Tríplice podem contribuir para inovações estratégicas através da tríade interdisciplinar de "organização", "inovação do modelo de negócios" e "fluxo de caixa financeiro" para destinar criação de valor ao ecossistema do projeto. Os resultados estão resumidos em um modelo de visão geral na mudança de interesse e compreensão básica de fluxo. Isso mostra que as discussões da Hélice Tríplice promovem uma abordagem significativa na conquista de inovações estratégicas para vantagens competitivas de ecossistemas produtores de energias renováveis. 


\title{
Russian
}

\section{Применение концепции тройной спирали в реализации стратегических инноваций в экосистемах прибрежных ветровых парков}

\author{
Тов Бринк
}

\begin{abstract}
Аннотация
В настоящем исследовании рассматривается управление портами в рамках трехспирального подхода и внедрение стратегических инноваций, способствующих снижению нормированной стоимости энергии в экосистемах прибрежных ветровых парков. Эмпирический качественный анализ был проведен за период с сентября 2017 по июнь 2018 при участии администрации порта, владельца ветрового парка и логистических операторов на море и на земле. Были проведены индивидуальные интервью, а также три совместных встречи, по итогам которых были получены материалы для исследования.

Результаты показывают, что администрация порта в рамках тройной спирали может реализовывать стратегические инновации посредством создания кроссотраслевого союза организаций, внедрять инновационные бизнес-модели и управлять финансовым потоком, способствуя созданию дополнительной ценности на уровне экосистемы проекта.

Выводы обобщены в виде модели для последующего анализа и оценки. Показано, что тройная спираль предоставляет достоверную модель для реализации стратегических инноваций и обеспечения конкурентных преимуществ в использовании возобновляемой ветровой энергии.
\end{abstract}




\section{Spanish}

\section{El marco de triple hélice contribuye a la innovación estratégica en ecosistemas de parques eólicos costeros}

Tove Brink

\section{Resumen}

Esta investigación muestra cómo las autoridades portuarias dentro del marco de la Triple Hélice pueden contribuir a la innovación estratégica reduciendo el Costo Nivelado de la Energía en los ecosistemas de parques eólicos costeros. El estudio de caso se realizó entre septiembre del 2017 a junio del 2018 con un puerto y un propietario de un parque eólico cercano a la costa danesa y dos empresarios de logística, uno que opera en tierra y el otro en alta mar. Basamos esta investigación en entrevistas individuales $\mathrm{y}$ tres reuniones que incluyeron a toda la red.

Las autoridades portuarias contribuyen a la innovación estratégica movilizando la trinidad de "organización", "innovación del modelo de negocio" y "flujo de caja” con el fin de crear valor al nivel del ecosistema. Resumimos nuestro análisis en un modelo que captura el flujo o proceso y los intereses que motivan el mismo. Allí mostramos que la Triple Hélice proporciona un marco de análisis y de gestión de la innovación estratégica que permite obtener una ventaja competitiva en el ecosistema de energía eólica renovable.

\section{Introduction}

Awareness of global climate change has increased considerably over the last decade. This awareness leads to considerable interest in renewable energy and related research (United Nations (UN), 2016; World Energy Council (WEC), 2017). According to the 'Energy Trilemma' (WEC, 2017) for providing secure, equitable and environmentally sensitive energy, more research is needed in the energy context. Many different energy sources are available, which increases the need to focus on the most promising renewable sources, as stressed by the Chair of the Worlds Energy Council, David Kim: 'As stewards of this [energy] industry, we all have a role to play in helping to make the right decisions that will provide a sustainable energy future for all' (WEC, 2017:4). This paper aims through qualitative empirical research to contribute to the insight for the right decisions. 
Offshore wind parks are situated in much more harsh contexts than onshore wind parks due to ever shifting and stormy wind conditions and salt water causing corrosion and slippery surfaces, e.g. transportation of technical employees is a challenge as they often can get sea sick with limited work potential on the wind turbines. Offshore wind parks are ecosystems often situated across national borders. They are placed in international waters with stakeholders from various countries (Brink, Madsen and Lutz, 2015). Literature streams within innovation highlight the notion of 'ecosystem networks' described as 'value creating interactions and relationships between sets of interconnected organizations' (Autio and Thomas, 2014: 205). Ecosystems networks are here perceived as value creation entities related through their value creation aims on system level. The interconnected ecosystem of the offshore wind park industry is stressed through the single measure for competitiveness among energy sources called the Levelized Cost of Energy (LCoE), which means the cost pr. MWh energy over the lifetime of the offshore wind park. The specific calculations vary depending on the more specific definition e.g. on discount rate in the period for calculation. On overall level the measure is accepted by stakeholders and briefly noted as 'the sum of the discounted lifetime generation costs $(€)$ divided by the sum of discounted lifetime electricity output (MWh)' (Crown estate, 2012). All projects within offshore wind parks thus have to aim for coherent strategic innovation for the overall reduction of LCoE for competitive advantage of offshore wind energy (Brink, Madsen and Lutz, 2015).

In offshore wind parks, LCoE is based on two issues: the production performance of energy in the nearshore/offshore wind park and the costs incurred regarding construction, production, installation, commissioning, O\&M and decommissioning. It is very important that the wind turbines continuously provide high-performance production of energy with reduced incurred costs, as highlighted in the notion of 'more for less' - also known as 'frugal innovation' (Radjou and Prabhu, 2015). The notion of frugal innovation is often associated with low-technical innovation. This is not the case in wind energy. Advanced technology is needed to succeed, which stresses the challenge to reduce LCoE even further. Collaboration in the ecosystem is thus called for to contain industrial private enterprises working on nearshore/offshore wind park projects, universities developing new knowledge for innovative activities and governmental bodies regulating and providing financial support for nearshore/offshore wind park energy. This collaborative ecosystem among different institutions is framed in the literature as a 'triple helix'. The triple helix is noted by Etzkowitz and Leydesdorff (2000) in their seminal paper as an institutional framework among the three parties of government, universities and industry to enable innovation in society. The parties in the framework typically 
have different interests (Leydesdorff and Meyer, 2006), as the government is primarily interested in social welfare, universities are primarily interested in new knowledge production and dissemination and industry is primarily interested in own economic gains. Overlapping interests e.g. universities in tech transfer earnings, companies in social responsibility can also be detected. The organizational frames of the participants are traditionally based on Transaction Cost Theory (TCE) as originally noted by Coase (1937) and elaborated by Williamson (1999), which basically compares the costs associated with two sources for the transaction - the external market and the internal organization (Williamson, 1999). Due to the TCE notion, it must be determined if it is more cost effective to coordinate the transaction through the external market (competition) or to have the organization oversee and manage the transaction (hierarchy). However, as shown by the innovation literature (Laursen and Salter, 2006), it is stressed that innovation performance is improved through organizational openness and collaboration. This means there is a need for network-organizational types, characterized by Podolny and Page (1998: 59) as 'any collection of two or more actors that pursue repeated, enduring exchange relations with one another and, at the same time, lack a legitimate organizational authority to arbitrate and resolve disputes that may arise during the exchange'. This can be seen in the offshore wind park scene, when country/ EU legislation hinder/ slow down/ contradict the offshore wind energy activities, because the legislation is made in other contexts. It can mean that the approval of an offshore wind park is postponed several years so that the technical development makes the original proposal obsolete and unsuitable adjustments have to be made afterwards to meet the governmental requirements for building the offshore wind park. Network theory typically highlights beneficial opportunities for network participants to engage in loosely coupled systems with easy and flexible access to necessary ideas and resources to which they may not otherwise have access. The notion of the triple helix enhances network understanding through explanation of the institutional frames reflecting the different interests underlying the entire ecosystem of government, universities and industry by providing an overview and language for the different interests and how they can overlap. Recent empirical research on the triple helix notion has shown that blurred boundaries can through cross-disciplinary approaches explore the context of these boundaries for a contribution to sustainable innovation within renewable offshore wind energy (Brink, 2017). This research shows that the organizing for innovation in regional innovation systems develops from fragmented innovation offshore wind park systems to the joint aim for competitiveness of offshore wind energy through reduction of the one-LCoE-measure. 
Strategic innovation aims at new considerable value creation long term, which involve significant commitment of resources and which is not easy reversible as noted by Grant (2016: 172): 'Strategic innovation typically involves creating value for customers from novel products, experiences, or models of product delivery'. Strategic innovation is perceived as a key source of competitive advantage, which 'often involves combining performance dimensions that were previously viewed as conflicting' (Grant, 2014: 173). It means long-term strategic direction with large commitments and investments to support survival. An example of conflicting views can be shown in the offshore wind scene through the LCoE- measure, which both contain increased production of energy with the use of less costs. Traditional views would accept increased costs to create better performance, which in the end hopefully can reduce the overall LCoE-measure. In wind energy both performance and costs have to be considered simultaneously on cross-disciplinary issues long-term. Empirical research in this field can thus support the understanding of strategic innovation on the triple helix ecosystem level with port authorities representing the government, universities and industries participating in the aim for strategic innovation. The research question is thus posed as follows: How can port authorities in a triple helix context contribute to the understanding of strategic innovation initiatives to reduce LCoE in nearshore wind park ecosystems?

The outline of the paper starts with highlighting the importance of the research topic for society, the challenges detected, the research question derived and the frame for the actors involved. Next, the theoretical framework sheds enhanced light on existing literature streams to form a cross-disciplinary anticipated proposition for research. Next, the methodology is explained. Then, the findings are analyzed and revealed for a summation in a model to provide the answer to the research question. Finally, the findings are discussed and concluded

Traditionally, port authorities are framed by governmental legislation as regulators and landlords for rent of square meters and equipment, and not as facilitators for collaborative innovation (Hollen, 2015) (e.g., as called for by nearshore/offshore wind energy respectively situated within and beyond national limits). However, the role of ports is changing as the main cargo types and associated activities have changed since the turn of the century. Ports basically provide spaces and facilities for logistic activities between land and water transport. Ports are corridors with spaces for activities as needed by the actors to create value. Many different actors exist in ports beyond the different actors from the offshore wind area, e.g. shipping services, ship yards, container activities etc. These actors can hinder development of the other actors if they occupy spaces, which could have been better used by other actors. Therefore, more 
facilitation in ports are needed to involve relevant actors and adjust for the best value creation for all involved. In the literature, it has been highlighted that ports consist of spatial sites of interwoven supply chains with independent yet interdependent firms (de Langen \& Haezendonck 2012; de Langen and van der Lugt, 2017) that, through interfirm network activities, can enable innovation (De Martino \& Morvillo 2008). This fact highlights that the ports' interests have to change not only in relation to nearshore/offshore wind park activities, but in general change. The quest is for collaborative business model innovation in interfirm networks; however, this stands in stark opposition to the hostility often revealed between firms in port spaces with different business models and political approaches, which make an impact on port activities (De Martino \& Morvillo 2008; De Martino, Carbone and Morvillo, 2015). It is thus difficult to get open discussions to understand and create joint innovation concepts as the first step for joint strategic execution. Ports are important actors in nearshore/offshore wind park energy as all actors in the offshore wind ecosystem are present in the port space. It means that research on the interests and activities in port spaces can make interesting contributions.

The aim for strategic innovation has a long-term perspective across different Business-to-Business (B2B) actors present both in construction, installation and long-term O\&M activities, where very heavy and costly facilities/ equipment are needed due to the huge size of the elements of nearshore/ offshore activities. These activities require an integrated combination of technical-, commercial-, logistic-on-land- and logistic-on-sea knowledge to enable innovation. Here the framing topic is the integrated combination of these topics as e.g. logistics is not important as such - logistics is here only interesting in combination with the support to technical- and commercial knowledge creation. This $\mathrm{B}_{2} \mathrm{~B}$ wind ecosystem context means larger transactions than in the Business-to-Consumer $\left(\mathrm{B}_{2} \mathrm{C}\right)$ context, with larger long-term investment in many of the participating organizations with strategic impact on the competitive advantage of the entire ecosystem (Hollensen, 2016). Therefore, a coherent strategic approach to innovation become important. Collaborative strategic innovation in the wind park ecosystem is thus needed.

Business model innovation (BMI) was first defined by Malhotra in 2000 as a paradigm shift involving the rethinking of business and organizational approaches, thus extending the scope beyond the level of business processes into the strategic considerations of the enterprise. This is different from traditional firm strategy, because the entire business process in the organization is perceived as a combined strategic issue - unique for each organization and not easy to copy by competitors. Malhotra stressed BM I as representing a '...radical rethinking of the business as well as the dividing lines between organizations and industries' (Malhotra 2000: 14). Since then, many definitions have been 
advanced, mainly rooted within streams of the innovation literature. The definition of BMI is often discussed according to the five types of innovation first noted by Schumpeter (1934) as products, processes, supply, markets, and organizations. However, as highlighted by Zott, Amit and Massa (2011), BMI can also be perceived as both a new type of innovation distinct from, and yet complementary to, the Schumpeterian notions of product, process, and organization. Limitations of the understanding of the BмI notion have been elaborated by Casadesus-Masanell and Zhu (2013), as they suggest BMI to comprise the fifth Schumpeterian innovation type of 'new ways to organize businesses'. The various types of definitions are dispersed; however, they underpin the organizational issue of $\mathrm{BMI}$, which is paramount at the business network ecosystem level in nearshore/offshore wind parks with many different organizations participating. In this paper the organisational issue in the definitions of вмI is elaborated through both individual and organizational behavior.

The development of the вмі literature has been fragmented, as shown by the research during the last decade (Foss \& Saebi, 2017; Schneider and Spieth, 2013). BMI activities originated in business models, as shown in the concept of Business Model Generation (BMG), (Osterwalder and Pigneur, 2010), and highlighted as 'business models themselves has increasingly been seen as subject to innovation' (Schneider and Spieth, 2013, p. 1340001-2). Research following BMI processes is scarce (Khanagha, Volberda and Oshri, 2014) as it is difficult to get access to these processes as researcher 'coming from outside' and with different organisations participating not knowing each other in work-relations on beforehand. Therefore, it can be anticipated that trust in the nearshore/offshore wind park ecosystem will be important, as shown by Kashiwagi (2009) and Walker and Walker (2016) in the construction industry. A need for more qualitative empirical research based on cross-disciplinary theories, which can reveal the BMI processes to support the strategic approach to innovation is present. Here traditional cost analyses can only represent a small part to reveal the joint BMI understanding and the behavior in the ecosystem organisations to make an empirical contribution to the offshore wind ecosystem and to triple helix literature.

The literature review will next enhance the theoretical framework for the development of a proposition derived from existing literature streams.

\section{Theoretical Framework}

The research conducted herein is situated within the cross-disciplinary literature streams of the triple helix, ecosystems, strategic innovation and BMI in the context of ports and nearshore/offshore wind energy to reduce LCoE. The 
literature streams are dispersed and follow specialized issues in the research. Activities in real life settings are typically cross-disciplinary, because different functions in an organization have to collaborate to provide a service or a product. Therefore, calls are often made within these literature streams for crossdisciplinary empirical research to provide enhanced insight and understanding of the complex issues contained in areas such as ports and the nearshore/ offshore wind park energy ecosystem to reduce LCoE (de Langen and van der Lugt, 2017; De Martino et al., 2015; Khanagha et al. 2014; Brink et al., 2015).

As highlighted in the triple helix literature, blurred boundaries between the different institutionalized actors in the ecosystem are suggested to enable innovation, because the blurred boundaries allow spill over between institutions (Leydesdorff and Meyer, 2006, Brink, 2017), as noted in the introduction. Here, the long-term single strategic measure of LCoE for successful innovation within nearshore/offshore wind park energy highlights the collaborative nature needed in this ecosystem to pursue BMI. Hitherto, the BмI literature has predominantly focused on the individual enterprise (Foss and Saebi, 2017; Schneider and Spieth, 2013). However, in the port context, where many actors are conducting activities together in the port, strategic innovation for collaborative вмI in the ecosystem is called for as highlighted in the introduction. The research participants are not used to work in a triple helix context, but they are open for participation to find out if the triple helix approach can be beneficial for their aim to reduce LCoE. BMI is predominantly an organizational concept, as already highlighted in the introduction. However, in the context of this research, collaborative вм becomes a strategic issue in this triple helix context because large, long-term commitments and investments are required for the competitive advantage of the ecosystem and the participating organisations.

Innovation has been elaborated by Amabile et al. (1996) as follows: 'Innovation is the successful implementation of creative ideas within an organization. In this view, creativity by individuals and teams is a starting point for innovation; the first is a necessary but not sufficient condition for the second'. (Amabile et al. (1996: 1154-1155). This means the use of new ideas for organizational knowledge creation is required to execute and control collective implementation successfully. This approach requires a combination of organizational behaviors and cultures to develop new ideas and create knowledge for people to support idea generation and successful innovation and implementation (Jung, 1968; Cameron and Quinn, 2011; Brink, 2016). This means that cross-disciplinary approaches utilizing heterogeneous organizational behaviors and culture to pursue innovative BMI directions, which can create value and positive cash flow in the ecosystem is required. This create a trinity of ability (organisational behavior), understanding essential joint business issues (BмІ) and value creation (cash flow). This trinity of essential cross-disciplinary issues is based on 
well-established knowledge in literature streams of 'organizational behavior', 'BMI' and 'financial cash flow' disciplines. In practical life a cycle of questions often emerges when this one-measure-LCoE-challenge comes up in the offshore wind park ecosystem on: can we do it? (organisation)? how will it be possible (вмI)? What impact on LCoE can we expect? (cashflow)? (Brink, Madsen and Lutz, 2015). These questions are used to frame the theoretical approach. It means that focused and acknowledged literature within these three disciplines can be used, which contain easy to understand concepts for the discussion of collaborative initiatives among the ecosystem's participants as revealed in the literature references in the next paragraph. The constructs are further elaborated in the methods and result sections to understand the first step for joint strategic execution and implementation.

Now literature on the three theoretical approaches are shown with focus on the underlying constructs for the research in this paper. First, the 'organizational behavior', and the derived organizational culture, is included for discussion in the ecosystem due to the literature on personal- and team-preferred behavior (Jung, 1968; Jacoby, 1973) and the competing value-framework of organizations (Cameron and Quinn, 2011) respectively based on the constructs of individual preferred behaviour of introversion contra extroversion (how persons respond to influences, respectively through an internal contra an external process), thinking contra feeling (how persons take decisions, respectively based on thinking contra feelings) and competing cultural values of internal contra external approaches (organisational integration contra differentiation) and stable contra flexible (organisational control contra discretion). This matrix of two $\mathrm{x}$ two dimensions of individual personal behavior hereby provide the overall four constructs of personal behavior with focus on respectively introvert-thinking (details), introvert-feeling (people), extrovert-feeling (ideas) and extrovert-thinking (goals). This has a spill over on the matrix of two $\mathrm{x}$ two dimensions of organisational behavior with focus on respectively internalstable (hierarchy), Internal-flexible (clan), external-flexible (adhocracy) and external-stable (market). The ecosystem enterprise organizations hereby obtain a joint language and understanding of preferred individual- and organizational behavior. Second, 'BмI' is based on the 'BMG' (Osterwalder and Pigneur, 2010) notion with the constructs from this design-based approach consisting of the following elements: customer segments, customer relations, channels, value proposition, key activities, key resources and key partners for the collaborative understanding of the ecosystem business project to encourage innovative activities for the development of BM I. In short this means that the value proposition forms a center for discussion of value creation for customer segments, customer relations and channels. This form enhanced discussions on how to provide the value proposition to customers through key activities, key resources 


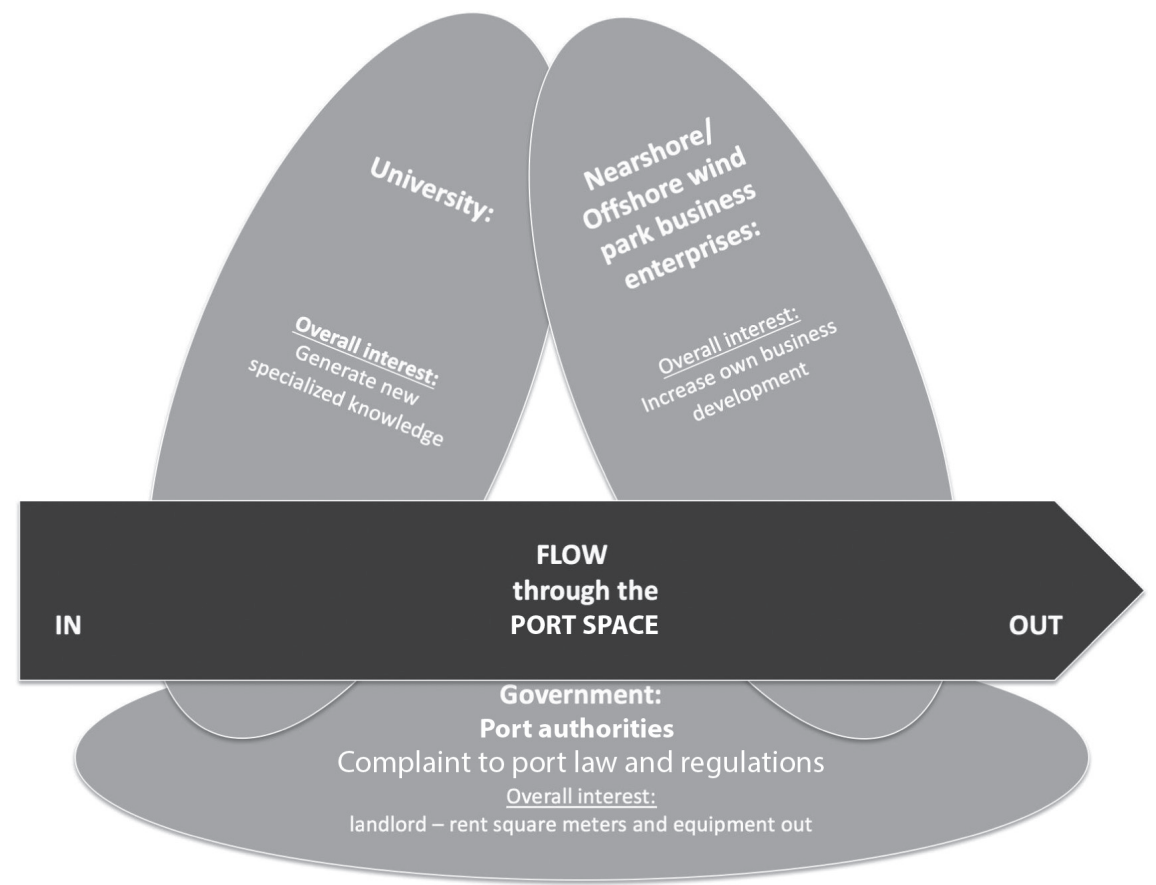

FIGURE 1 Overview on the theoretical frame for the triple helix research approach.

and key partners. Third, 'financial cash flow' (Koller, Goedhardt and Wessels, 2010) shows the parameters sales, earnings before interests and tax and depreciation (EBITDA), working capital and investments for the calculation of return on BMI initiatives to pursue strategic innovation. This trinity of essential cross-disciplinary issues forms the ability of the involved organizations, the collaborative development direction of вмг initiatives and the joint understanding of cash flow return for strategic innovation initiatives to reduce LCoE for competitive advantage of the ecosystem.

In Figure 1 the illustration shows the overall different interest noted in the triple helix literature.

Figure 1 shows the flow in the port system for the reduction of LCoE with nearshore/offshore wind park elements coming into the port for handling in the port space, and then leaving the port space again for energy production at sea. This sets a frame for the institutional triple helix participants. The triple helix parties are shown, with the government represented by the port authorities' compliance with laws and regulations set by the government. Nearshore/ offshore wind park business enterprises are shown to provide knowledge applications for business development upon future needs. Universities are shown to generate and develop new and typical specialized knowledge within 
disciplines for dissemination. In the research, the universities also facilitate the active learning process.

The present research approach requires that the enterprises can leave behind their typical competitive approach to other enterprises in the port context. This proposition takes point of origin in the port and port spaces, which set the arena for the nearshore/offshore wind energy ecosystem. The following proposition can be derived from the elaborated cross-disciplinary theoretical framework:

Port authorities can, through discussion, in the triple helix context, of organizational behavior, BMI and financial cash flow on an ecosystem project level, enable strategic innovation in port spaces.

This forms a different and more coherent approach than the fragmented research approaches in the noted literature streams.

\section{Methods}

This research is conducted within the renewable nearshore/offshore wind park energy context. Nearshore and offshore wind energy is desirable because they overcome the onshore challenges faced by people living near wind turbines. Additionally, stronger winds at sea can enhance renewable energy production (Brink et al., 2015; IRENA, 2016). Research is limited in the nearshore/ offshore wind park and port ecosystem context. This limitation means that this research field is underdeveloped, and a qualitative research approach to understanding the important phenomena situated in the ecosystem is required (Eisenhardt, 1989; Yin, 2009; Miles, Huberman and Saldana, 2014). In the qualitative research approach, replication logic is present, which is different from the sampling logic used in quantitative research (Yin, 2009:54-60). This means that the research approach must be described so that replication is possible in the same or different contexts by other researchers. Therefore, the research activities are explained to help others understand the research approach and context for this empirical qualitative case study conducted from September 2017 to June 2018 in a port close to nearshore wind park sites in the Baltic Sea.

This research was designed as a deductive project-based ecosystem case study at nearshore wind parks with similar harsh conditions present both nearshore and offshore. It was decided to take a deductive approach for research in this study, because well-established literature streams and constructs as shown in the theoretical framework were anticipated to shed light on the research question posed. The study was designed using an empirical action 
learning approach, which can consecutively reveal essential issues for collaborative BMI to enable strategic innovation in the ecosystem. The participants in the research was selected through a snowball sampling (Miles, Huberman and Saldana, 2014; 32 ) because the investigation of the strategic purpose in the case is important and therefore essential partners need to be present. The snowball started with meetings with the port. The port selected the wind park owner, which they briefly had talked to before about the nearshore ecosystem project. The wind park owner selected the logistic partner at Sea, which they perceived interesting as they had not had work conducted at sea before. Both the port and the offshore project owner selected the logistic partner at land, because they were conducting interesting innovative projects internationally. The research participants therefore had limited knowledge about each other even though it was a 'snowball sampling'. However, all participants perceived this triple helix approach as an interesting approach to achieve strategic innovation.

The research started with individual interviews with the nearshore park owner, the nearby port and a logistic business actor operating on land and one operating at sea. These individual research meetings lasted approximately $3-5$ hours each and were conducted before the first collaborative action learning network meeting. Two managers from each organization participated in the research process.

In the individual interviews with each enterprise, the discussion was focused on the trinity as shown in the section on the theoretical frame in the research of 'organization', 'вм I' and 'financial cash flow' and the initiatives necessary for project initiatives to enable strategic innovation to reduce LCoE. A summation of the individual meetings was presented by one of the respective participants from each of the enterprises at the first joint network meeting. This caused an open sharing of each organization's understanding of the nearshore ecosystem project and understanding of the participating managers and their organizations. The discussion was engaged with many questions to reveal a better understanding of both. Thorough, insight was generated for enhanced knowledge creation during the three network meetings, which took place at the end of October 2017, lasting 6 hours; at the beginning of March 2018, lasting 7 hours; and at the end of May 2018, lasting 6 hours. At the first network meeting, the challenges in the ecosystem project were discussed. The participants wanted more detailed knowledge about each-other's actual activities to enable BMI and strategic innovation. From the initial four individual interviews the participating organisations had suggested 3-5 different projects, which could be interesting to pursue in this research on ecosystem level. There was an overlapping issue between the suggestions from the organisations on some kind of discussion of flow through the port - seen by some as a 
specific simulation. After discussion among the participants it was thus decided to select the joint project for physical simulation with ${ }_{3} \mathrm{D}$ printed wind turbine elements, ships, cranes, etc. in a model of the participating port for joint elaboration of strategic innovation initiatives in the rest of the network meetings. During the second network meeting, the simulation was conducted by the research participants, and thorough discussions unfolded for the development of opportunities for strategic innovation. During the third network meeting, a follow up to the developed innovation concepts was carried out with special focus on the investments required in the port, and presentation of the concept was given to a wind turbine producer for comments. The interviews/meetings were transcribed and analyzed for support and/or rejection of the proposition to provide a more detailed understanding of the process and strategic innovation initiatives. A short overview is listed in the table below on both anonymous enterprise information and the research process conducted. The participants were managers with several years of work experience on offshore wind projects in port spaces. They did clearly represent their organisations perspectives as they were the responsible persons for the offshore wind project activities in the port spaces. No direct representatives from the government was participating and the university participants had the role of facilitators for knowledge creation with funding for other researchers to participate on demand. Here researchers from the technical faculty was called for on the $3^{\mathrm{D}}$ printing issue during the research process.

In Table 1, the research participants are shown as anonymous. However, it can be seen that the participants have different approaches and very different experiences and knowledge based on activities hitherto. The content in the research process is developed by the research participants based on their own organizations and the joint project BMI, as well as the anticipated financial cash flow from BMI initiatives. Hereby important joint interaction processes can be detected during research. The research participants were into collaborative detailed design of the network meetings on the meeting immediately before the network meeting in question. The trinity research approach of the first individual interview was accepted by the participants when they joined the research.

In the individual meetings, the preferred behavior and organizational cultures of the research participants were revealed through a personal profile questionnaire using the acknowledge Insights ${ }^{\circ}$ tool (Benton, Schurink and Desson, 2008) based on Jung's (1968) theory of archetypes. Nearly all European personal profile tests are based on Jung's theory. From this approach, the organizational culture was also derived through discussions on the meeting in a graphical illustration of the 'competing values framework' (Cameron and Quinn, 2011) in the enterprises. The two constructs on personal profile and 
TABLE 1 Overview of enterprises and the research process.

\begin{tabular}{|c|c|c|}
\hline Role & $\begin{array}{l}\text { Enterprise Information } \\
\text { ( EU definition on size of enterprise) }\end{array}$ & Research project \\
\hline Port & $\begin{array}{l}\text { Enterprise - owned by the Municipal Community with compliance to the } \\
\text { port Law of the country. } \\
\text { Medium size enterprise } \\
\text { Two managers on offshore wind. \& port activities participating. } \\
\text { Preferred behavior: details and goals } \\
\text { Organisational culture: hierarchy and market } \\
\text { Overall interest: rent square meters and equipment out as a landlord }\end{array}$ & $\begin{array}{l}\text { 0. Phase: } \\
\qquad \begin{array}{l}\text { Initial individual meetings } \\
\text { with the enterprises in } \\
\text { September - October } 2017\end{array}\end{array}$ \\
\hline $\begin{array}{l}\text { Nearshore } \\
\text { Wind park } \\
\text { owner }\end{array}$ & $\begin{array}{l}\text { Enterprise - owned privately. } \\
\text { Medium size enterprise } \\
\text { Two managers on offshore wind commercial \& technical issues. } \\
\text { Preferred behavior: goals, details and people } \\
\text { Organisational culture: market and adhocracy } \\
\text { Overall interest: Increasing own business development }\end{array}$ & $\begin{array}{l}\text { 1. Phase: } \\
\text { First network meeting in } \\
\text { end October } 2017\end{array}$ \\
\hline $\begin{array}{l}\text { Logistic } \\
\text { partner at } \\
\text { sea }\end{array}$ & $\begin{array}{l}\text { Enterprise - owned privately. } \\
\text { Larger size enterprise } \\
\text { Two managers on offshore wind business development \& port activities } \\
\text { Preferred behavior: goals and ideas } \\
\text { Organisational culture: all four } \\
\text { Overall interest: Increasing own business development }\end{array}$ & $\begin{array}{l}\text { 2. Phase: } \\
\text { Second network meeting in } \\
\text { start of March } 2018\end{array}$ \\
\hline $\begin{array}{l}\text { Logistic } \\
\text { Partner at } \\
\text { land }\end{array}$ & $\begin{array}{l}\text { Enterprise - owned privately. } \\
\text { Larger size enterprise } \\
\text { Two managers on offshore wind business development \& port activities } \\
\text { Preferred behavior: goals and details } \\
\text { Organisational culture: market and hierarchy } \\
\text { Overall interest: Increasing own business development }\end{array}$ & $\begin{array}{l}\text { 3. Phase: } \\
\text { Third network meeting in } \\
\text { end May } 2018\end{array}$ \\
\hline
\end{tabular}

organizational culture fit very intuitive together and therefore they are easy to use in combination for research participants. The ecosystem project BMG was developed on the meeting through joint discussions and elaboration of the illustration to provide BM I project opportunities with derived impact on cash flow parameters and reduction of LCoE. It was shown through the individual personal profile tests that the preferred personal behaviors of the participants are distributed among the four personality types with different focus on details, people, ideas and goals, with the majority of participants focusing on goals and details. However, all four personality types were represented. From the understanding of individual preferred behavior, the overlapping understanding can be created for the different organisational cultures. The organizational cultures were also distributed among the four culture dimensions of hierarchy, clan, adhocracy and market, but emphasizing hierarchy and market the most. Table 2 illustrates the findings on preferred individual- and organisational behavior.

Table 2 shows that heterogeneous antecedents for the different triple helix actors to understand themselves and their organization and understand the others in the same way is present in the research. This can help to create insights on each other despite of different triple helix spheres. The heterogeneity required for the development of innovation was thus present in the research 
TABLE 2 Overview of preferred individual- and organizational behavior.

\begin{tabular}{|c|c|c|c|c|}
\hline $\begin{array}{l}\text { Personal } \\
\text { types }\end{array}$ & $\begin{array}{l}\text { Description of } \\
\text { characteristics }\end{array}$ & $\begin{array}{l}\text { Individual } \\
\text { profiles } \\
\text { - Number of } \\
\text { participants }\end{array}$ & $\begin{array}{l}\text { Description of } \\
\text { organizational } \\
\text { culture }\end{array}$ & $\begin{array}{l}\text { Organizational } \\
\text { profiles } \\
\text { - Characteristics of } \\
\text { organizational } \\
\text { culture }\end{array}$ \\
\hline $\begin{array}{l}\text { Introvert } \\
\text { thinking }\end{array}$ & $\begin{array}{l}\text { Focus on } \\
\text { details } \\
\text { regarding tasks }\end{array}$ & & $\begin{array}{c}\text { Hierarchy } \\
\text { Control and efficiency } \\
\text { with capable } \\
\text { processes produce } \\
\text { effectiveness }\end{array}$ & \\
\hline $\begin{array}{l}\text { Introvert } \\
\text { feeling }\end{array}$ & $\begin{array}{l}\text { Focus on } \\
\text { people } \\
\text { and impact on } \\
\text { them }\end{array}$ & & $\begin{array}{l}\text { Clan } \\
\text { Human development } \\
\text { and participation } \\
\text { produce effectiveness }\end{array}$ & \\
\hline $\begin{array}{l}\text { Extrovert } \\
\text { feeling }\end{array}$ & $\begin{array}{l}\text { Focus on } \\
\text { new ideas } \\
\text { involving people }\end{array}$ & & $\begin{array}{l}\text { Adhocracy } \\
\text { Innovativeness, } \\
\text { vision, and new } \\
\text { resources produce } \\
\text { effectiveness }\end{array}$ & \\
\hline $\begin{array}{l}\text { Extrovert } \\
\text { thinking }\end{array}$ & $\begin{array}{l}\text { Focus on } \\
\text { goals } \\
\text { and competitive } \\
\text { actions }\end{array}$ & & $\begin{array}{c}\text { Market } \\
\text { Aggressively } \\
\text { competing and } \\
\text { customer focus } \\
\text { produce effectiveness }\end{array}$ & \\
\hline
\end{tabular}

through distributed organizational behavior and organizational cultures. Moreover, the ecosystem project BMG provided an overview for the participants of their own contribution to the near shore/offshore ecosystem for the joint discussion of opportunities of strategic innovation for financial cash flow and the reduction of LCoE. The research participants had a very positive evaluation of the action research process in the end as one of the participants framed it:

This process opens new ways to understand value creation in offshore wind park projects. This is interesting for us and it will get even more interesting when we can use the insight and understanding in the specific subsequent projects

Several of the research participants stressed that this knowledge could not have been created in other contexts than this triple helix sphere, where essential questions could be answered and further elaborated together with triple helix actors with a lot of practical experience. The knowledge created during research can be used again and again by all the participants in subsequent projects, e.g. knowhow for development of a flexible roll off and roll on procedures 
for the large offshore wind components without use of cranes. It means less slow down of flow and less damage and accidents.

The interviews and meetings were transcribed and analyzed to support or reject the proposition developed in the theoretical framework as follows:

Port authorities can, through discussion, in the triple helix context, of organizational behavior, BMI and financial cash flow on an ecosystem project level, enable strategic innovation in port spaces.

Additionally, these data and analyses provide answers to the research question. A research team of two senior researchers and a student assistant conducted the practical research, data collection and transcriptions. Hereby a discussion unfolded during research for investor triangulation of the phenomena studied consecutively.

Next, the results will be discussed.

\section{$4 \quad$ Results}

The analyses will, in the triple helix context of research, take point of origin in the strategic innovation process at the ecosystem project level. Then, the impact of the revealed strategic innovation initiatives will be elaborated. Finally, the interaction of the triple helix parties to enable strategic innovation will be analyzed. The results will be summarized in a model to support the answer to the posed research question of how port authorities in a triple helix context can contribute to the understanding of strategic innovation initiatives to reduce $L C o E$ in nearshore wind park ecosystems?

First, the strategic innovation process at the ecosystem project level will be shown.

The process of developing strategic innovation at the ecosystem project level in the port.

Through the design-based approach to B $\mathrm{MI}$ it was easy for the research participants to create the project ecosystem BMG canvas (Osterwalder and Pigneur, 2010:44) to be used in later meetings to collaborate on joint BMI at the business network level. In the individual enterprise interviews at the beginning of the research, the following areas were filled out with suggestions according to the interviewee's perception at the project ecosystem level of offshore wind parks. The analyses of the data provided will be done subsequently in this section on the areas: 
- Customer segments

- Customer relations

- Channels

- Value proposition

- Key activities

- Key resources

- Key partners

The research participants typically perceived the range of value-adding activities to the end-consumer of energy. In this way, different 'other customers' were identified, such as new future owners of the nearshore wind park and Original Equipment Manufacturers (OEMs) buying products and services. The participating present owner of the nearshore wind park sites had especially good insight on customer segments, customer relations and channels for value-adding вмI activities along the way to the end-consumer of energy demanding reduction of $\mathrm{LCoE}$. This was also found in previous research regarding offshore wind parks (Brink, 2017).

All participants provided thorough insight and understanding of the value proposition on the project ecosystem level as perceived through their lenses. A main overlapping issue was mentioned as the need for reduction of LCoE, but two other issues were also frequently mentioned:

1. 'Safe handling of wind turbine elements', which means to secure the flow from production to installation and operation and maintenance (O\&M) of the wind turbine for materials and people - without reworking and accidents hurting people and destroying materials and equipment.

2. 'No extra use of time spent waiting for other activities in the wind turbine flow', which means that no time is wasted on the way for wind turbine energy production in the wind parks.

The issues mentioned as number one and two also relate to reduction to the lowest possible costs, such as ensuring no rework needs to be done/no one gets hurt with potential increase in energy production performance in the wind park. The installation is done as soon as possible without 'loss of possible production from wind', and no cost is incurred for rework, accidents, storage and waiting times of personnel, ships, jack-ups, cranes and other very costly equipment. The participants thus highlighted that the valuable proposition at the ecosystem project level was the reduction of LCoE through two pursued aims:

- Earlier and more steady utilization of wind for energy production increasing performance.

- No extra costs for rework, claims, compensations and waiting - reduction of incurred costs. 
The industry enterprise participants in the research perceived the two pursued aims through their own lenses (e.g., the logistic participants both at sea and on land were very focused on different key activities for providing the value proposition respectively on land and at sea).

The value proposition was through the contribution by the port extended to include 'no inconvenience' for the inhabitants of the hinterland of the port (e.g., no noise, dust and traffic irregularities), and the need for compliance with the Danish Port Law stated by the government as listed below:

- No indirect costs experienced by communities and other enterprises reduction of incurred cost.

- Compliance with national laws and regulations - providing sustainable energy in a sustainable way.

These issues have again a spill over on the LCoE-measure and can thus be summarized into the value proposition of the reduction of LCoE. Hereby an enhanced understanding of the value proposition could be identified at the joint project ecosystem level.

Customer relations and channels were often perceived in relation to how the participants 'work to be able to send an invoice'. However, during the discussions the participants expressed the greater potential for project managers to understand the needs of the customers customer and partners, because their needs in the end of the day are essential for long-term competitive advantage. Therefore, an enhanced approach is needed on the understanding of the different customers present in the ecosystem ending at the different end-user consumption. Customers $\mathrm{B}_{2} \mathrm{~B}$ and $\mathrm{B}_{2} \mathrm{C}$ contexts were typically addressed by the participating wind park owner as knowledge about these customers were primarily present in the wind park owner organisation. Fruitful discussions between the research participants could then unfold on the whole value system of renewable wind energy production with the participants contributing with their own knowledge and questions to the collaborative understanding of the value proposition and key activities, resources and partners.

The key activities where typically highlighted through the participants own lenses, as:

- Logistic activities on land (logistic partner land)

- Logistic activities on the Sea (logistic partner Sea)

- Selling Energy to end-user, business to businesses and/or private users (wind park Owner)

- Renting port spaces out (port)

However often the participants due to their own lenses and own knowledge of key activities ran into challenges in understanding what they came to call 'interfaces' understood as the points of transfer between business partner 
organisations e.g. technical-, commercial- and logistic processes between land and Sea and vice versa, e.g. transfer of wind turbines from the овм to the wind park owner and transfer of the wind turbines through the port integrating technical- and commercial activities often called 'flow' by the participants. Therefore, issues of 'interfaces' and 'flows' where often discussed during the network meetings for more proper key activities for solutions with enhanced value proposition.

The focus on key resources was typically found in different knowledge domains, such as IT data system collection and data mining, availability of financial resources and project management, which represent both explicit and tacit key resources. The typical direct customer of the logistic participants in the research is the wind turbine oEm, which provide the dominant component. However, the participants expressed the greater potential for project managers to understand the needs of the customers (e.g., the nearshore project owners and other partners), because these needs are essential for competitive advantage. They said: 'the market is large enough for all of us, when offshore wind energy can compete with traditional energy sources'. Therefore, the reduction of LCoE is required through both explicit and tacit key knowledge creation and application in key knowledge domains as IT data collection in the entire ecosystem and datamining for all triple helix partners in the research. This is not only requested for flow in the port space but also reaching out to the end consumer of wind energy. The port, which is framed through government authorities first and foremost focused on key resources, such as the facilities at the port (e.g., water depth, berth length, carry ability on the quayside, buildings, cranes and number of square meters idle in the port and where these square meters are situated). The port also perceived the application of knowledge as important, but as something that could be learned as the project unfolded due to previous experience with earlier offshore wind park projects conducted in the port.

Key partners were not mentioned much, however, IT and legislative areas were noted as data collection for improvement of 'flows' and 'interfaces' and use of specific resources in these areas are important for knowledge creation to understand the interfaces and flows and to regulate the important issues found. The research participants agreed that key partners in the future could be important for collaborative initiatives with capabilities in IT- and legal areas. It was suggested that these partners maybe need to come from 'outside' the present offshore ecosystem to provide fresh insights to the current understanding.

Through these more detailed insights on the value proposition, a more meaningful discussion could unfold at the first joint network meeting for BмI 
to enable strategic innovation in the ecosystem. Additionally, the heterogeneity of preferred behavior of the research participants (as shown in table 2) provided thorough discussions on e.g. technical details, commercial goals, new ideas and the impact on people in general and in the organisations participating in the ecosystem. Additionally, the heterogeneity of organizational culture developed the organizational understanding of the ecosystem participants to support LCoE and avoid hindrances. This provided a common language as the discussion went on not only regarding individual behavior and organisational behavior, but also on the difficult issues for strategic innovation in port spaces identified by the participants as 'flow' and 'interfaces' between ecosystempartners. These understandings helped to build trust as the participants could discuss their understanding openly and with new ideas and suggestions taken into consideration by all participants. The 'financial cash flow' perceptions helped participants to propose and select initiatives for strategic innovation at the ecosystem project level. This was predominantly rough estimates, which was compared to the previous experiences held by the research participants.

The proposition on the anticipated beneficial impact from discussion in triple helix context of organizational behavior, BMI and financial cash flow on the ecosystem project level is thus supported., because all three issues playd an important role in the strategic innovation process as highlighted. Rich information is present from the transcription of the activities and process with the research participants, who provided an enhanced insight and understanding of the processes needed at the ecosystem project level. This was shown from the first joint network meeting, where the participants were engaged and interested to hear and discuss issues on the trinity with an open and innovative approach. This engaged approach continued through the three network meetings. All details cannot be provided in this article - there is only room for examples and summarized results.

In the next part, an elaboration of the impact of the strategic innovation initiatives will be conducted. Focus is held on the offshore wind park participants as there is plenty of available space in this port with few other actors involved in activities in the port space.

\section{The impact on strategic innovation activities in the port space.}

The joint discussion derived from the contributions of all participants developed in two directions:

1. The strategic innovative business case solution for nearshore wind parks close to the port.

2. A hub function for offshore wind parks in the Baltic Sea - strategic investments 50 years ahead so that two large offshore wind park installations can run through the port simultaneously. 
Originally, only the first direction was an object of the research. However, during the discussions among the participating ecosystem organizations, the second strategic opportunity for the port emerged. The triple helix frame thus provided a thorough discussion through the three lenses, with questions posed such as: 'How many larger wind park installations can run through the port simultaneously?' and 'How many offshore wind parks will be required simultaneously in the Baltic Sea?' Here, the trade-off between the distance at sea and the ability of strategic innovative knowledge creation in the port space for reduction of LCoE becomes important. The discussions of these questions in the triple helix frame provided a new insight on the hub-port idea, which came from one of the participants. Initially, the port did not believe in the hub-port idea, but as the discussions unfolded on the questions with the different triple helix participants to make their contribution to the idea, it was revealed as an interesting idea - not only for the port, but also for the other research participants as future activities regarding the Baltic Sea could take point of departure close to other activities conducted by the actors.

The research participants emphasized innovative knowledge generation as very important, because authorities in other countries compared to Denmark along the Baltic Sea were perceived as very rigid and based on rules developed in a time with less complex and more monotonous processes in ports. This is very different from the requirements needed for handling nearshore/offshore wind park elements in ports. The 'hub-function' was a new opportunity not envisioned earlier by the participating port and is of high importance for strategic innovation in the port reaching $30-50$ years ahead. Basically, the idea came from one of the research participants - the person with focus on new ideas as preferred behavior and was elaborated in continuous discussions by the other triple helix participants with different preferred behaviors. A hubport function means that all offshore wind park activities takes point of departure in this port, which through efficient and effective handling of flow and interfaces can provide value and reduction of LCoE to wind farms in long distance in the Baltic Sea. The open discussion in the ecosystem context thus provided interesting opportunities for the governmental party of the triple helix - represented by the port authorities - and for governmental legislation to become an enabler for strategic innovation in the ecosystem, not limiting innovation through rigid legislation and procedures hindering the flow and security of interfaces between ecosystem participants. The triple helix relations provided a base for enhanced institutional discussion not only on legislation but also on training and knowledge creation of the different participants and the development of the hinterland to the port to support the hub-port opportunity. 
Additionally, the estimate of investments required for reaching a hub function for the port in the Baltic Sea was approximately halved during the discussion. Suggestions on how to handle the elements faster through a continuous flow through the port with flexibility of facilities and roll on-roll off facilities for more secure and fast handling of wind turbine elements supported lower O\&M cost and investment and earlier production from the offshore wind park sites. The load of the hinterland to the port was also discussed for innovative solutions to relieve noise, dust and traffic irregularities. This was part of the value proposition for the project at ecosystem level originally noted by the port and summarized as 'no inconvenience' for the hinterland. The port thus played an important role for providing value to the public hinterland and provide safe working conditions for the involved employees and less damage of equipment. This shows an increased value proposition through joint efforts in the ecosystem due to the triple helix context. As noted by the research participants: 'The knowledge created through these processes is not complex technical knowledge, but it can have a considerable impact on the reduction of LCoE'. Primarily the knowledge created was on combined processes concerning technical-, commercial-, logistic on land and logistics on sea activities, which cannot be obtained elsewhere than in this ecosystem triple helix context.

The proposition anticipating that port authorities, through discussion of organizational behavior, BMI and financial cashflow on the ecosystem project level, can enable strategic innovation in port spaces is therefore supported as stated by the the consensus opinion of the research participants regarding the research processes and the results achieved. The open discussions provided enhanced strategic innovation opportunities for the reduction of LCoE. Finally, the next part will shed light on how the triple helix frame actually enhanced discussions to achieve the listed strategic innovative activities.

\section{Interaction of triple helix participants to enable strategic innovation.}

The triple helix participants are represented in the research through

- 'Governmental bodies' - the participating port - regulated by the Danish Port Law.

- 'Industry' - the participating nearshore park owner and the logistic enterprises at sea/on land.

- 'University' - the participating research team with potential involvement of other researchers on demand e.g. from the technical faculty and other social science researchers.

From the beginning of the triple helix discussions, it was apparent that the industry participants were talking about the 'enhanced flow through the port in and out', where this flow came from, the content and the destination. 
The industry participants were asking questions about how the flow could be supported primarily to the port participants and among themselves and secondarily to the university participants, which could pass the questions on to other researchers if the research team could not answer the questions. The port participants were talking about facilities and how these facilities had previously been used and were at present used for different activities. The awareness of the importance of flow was limited but was, as the port participants said, 'interesting to hear about'. The university participants through the research team were talking about the theoretical frame and asked questions about applications in the context of 'organization', 'BMI' and 'financial cash flow'. The focused ecosystem action learning approach found different essentials through these lenses. It means creation of explicit and tacit embedded knowledge e.g. on project management in projects at ecosystem level; the participants noted: 'we cannot obtain this important knowledge anywhere else there is no knowledge available or present context suitable to develop this knowledge'.

This provided an interest of the research team and research projects connected to the university to 'generate new cross-disciplinary knowledge', which can then be used for further research and dissemination. The university participants have a neutral approach with a focus on knowledge creation with no other specific business interests involved, as the university is not involved in technology transfer on this topic. It means that the typical interest of the university has changed from 'generating new specialized knowledge' to 'generating new cross-disciplinary knowledge' as interesting further research opportunities have emerged as well for the research team as the other researchers involved from the technical faculty and other social science researchers.

During the research process, the interests of the nearshore/offshore wind park business network participants also changed from 'increasing own business development' to 'open collaborative project ecosystem initiatives for strategic innovation'. During the research process, open joint organizational knowledge creation unfolded, having a considerable impact on strategic innovation initiatives to reduce LCoE. As the business participants mentioned 'You give something (ideas and knowledge) and you lose something (shortterm own business-as-usual approaches), but in the end we all gain by open exchange of information and joint knowledge creation. The interest of the port changed from 'traditional regulation' to 'facilitating strategic innovation in the ecosystem. The research approach provides changed frames for knowledge creation, which can support double loop learning as noted originally by Argyris (1977), e.g. this is shown in the hub-port opportunity developed during the 
research process. The facilitation is embedded in the subsequent strategic decisions of the port, with derived impact on daily operations.

Overall, the analyses provide support for the entire proposition that port authorities, through discussion in the triple helix context of organizational behavior, BMI and financial cash flow on the ecosystem project level, can enable strategic innovation in port spaces. Innovation was actually revealed on several levels. Especially, strategic innovation was reached through halving the necessary investments and still obtain an improved flow through the port and improved security in the interfaces between different partners handling e.g. wind turbines, blades and nacelles. Moreover, an opportunity for the port to become hub-port for the Baltic Sea was developed as highlighted earlier in this result section.

\subsection{Summary of Results}

Figure 2 provides a graphical illustration of the essential issues revealed in the research

Figure 2 highlights two issues, which are important for the port to enable strategic innovation in this triple helix context:

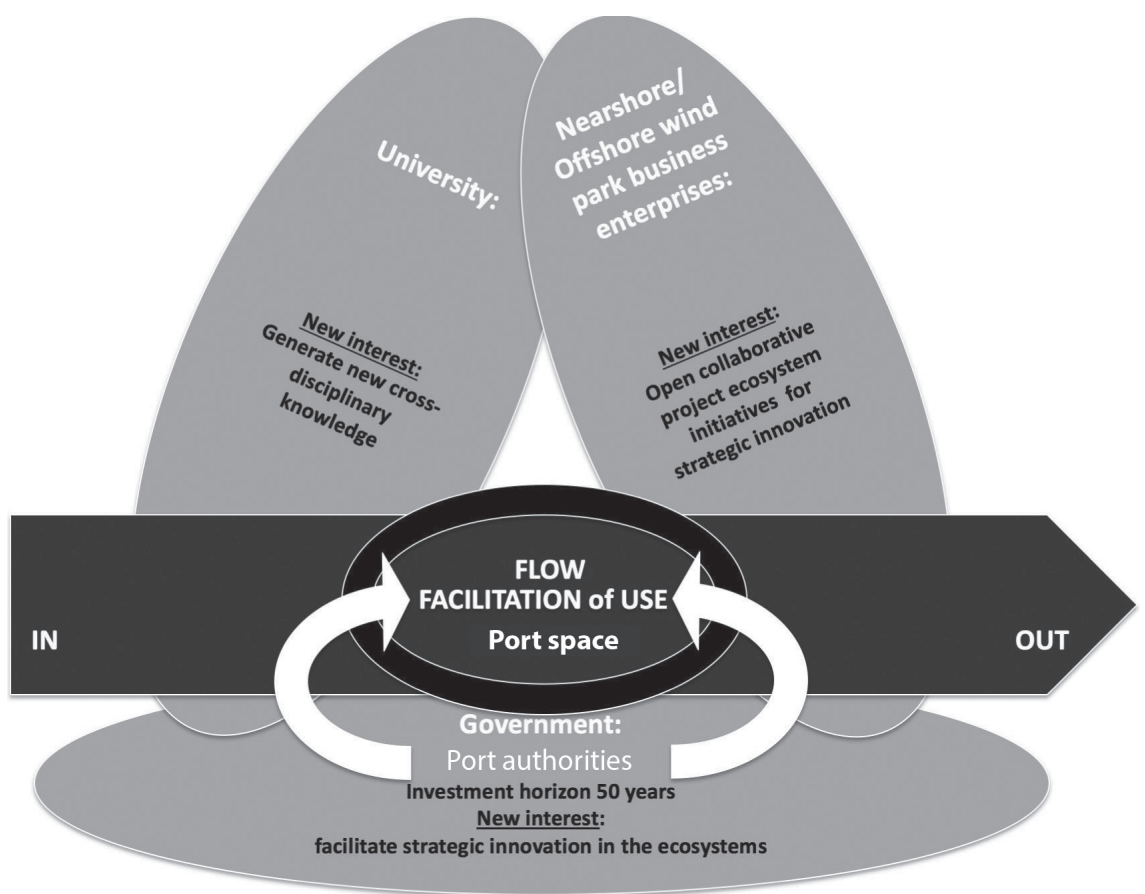

FIGURE 2 Summary for port authorities to enable strategic innovation. 
1. Facilitation of the use of the port space through a joint understanding of the value proposition at the project ecosystem level.

2. Integrate the differences in interests and time-horizons of the triple helix parties for the ability of the ecosystem to fulfill the overall project value proposition.

Ports have opportunities to facilitate the use of port spaces for strategic innovation to benefit society in the renewable offshore wind energy context. This has both strategic and operational impacts on the port activities and therefore the port authorities themselves must take responsibility for facilitation. The facilitation cannot in the future long-run be left to universities, as universities have to continue the development of new cross-disciplinary knowledge in other contexts. Simultaneously, the port has to integrate the gap in timehorizon between the typical relative short-term activities in the business networks and the long-term activities and investments needed in port spaces. Flexibility, sharing of resources and reuse of equipment and material play important roles in the port business result and for funding authorities.

The developed model in Figure 2 makes contributions to port authorities, business enterprises and universities on how they can enable strategic innovation in the nearshore/offshore wind energy ecosystem. Port authorities can facilitate the efficient and effective use of port spaces through open discussions within the coherent trinity of 'organization', 'BмI' and 'financial cash flow', with due consideration paid to the gap in time horizon between port authorities and business network activities. The business network participants can enable strategic innovation through an open, collaborative participation in the project ecosystem discussion. Universities can enable strategic innovation through cross-disciplinary research methods and literature development for further research and dissemination. Contributions from this research are then made to all participants in the triple helix context, especially in terms of how the parties can be connected across the boundaries of the organisations in the nearshore/offshore wind park ecosystems in this triple helix context for continuous loops of learning as noted by Argyris (1977) as 'double loop learning'.

\section{5}

\section{Discussion}

This research departs from the port lens because the research is conducted within the port space, which means the physical space provided for actor activities at the port. However, the research actually shows the results extend beyond the port space as the interests can shift for all the institutionalized 
triple helix participants as shown in Figure 1 (point of departure of interests of participants) and Figure 2 (resulting interests of participants noted after the research process ended). In between the interests of participants have changed due to project collaboration activities at ecosystem level in triple helix context (Leydesdorff and Meyer, 2006; Brink, 2017). The participative active learning approach transcends the boundaries of the institutionalized triple helix parties to develop double loop learning (Argyris, 1977) for new innovative solutions for e.g. halving the investments required and developing the hub-port suggestion for the Baltic Sea. Universities can develop cross-disciplinary knowledge to enable strategic innovation for the renewable energy ecosystem. This has a limited focus, for example in the Danish University Law, which Danish universities have to comply with to be able to get the funding provided by the Danish State. The research highlights that more focus is needed on the ecosystem processes, as already suggested by Foss and Saebi (2017) and as noted by Schneider and Spieth (2013:34) with focus on 'the processes and elements of вмI, as well as enablers and effects need more attention'. It is important to understand the ecosystem processes to understand and transcend the complexness added on the ecosystem level. Hereby an agreed simplicity can be obtained. More research is called for on cross-disciplinary issues, e.g. individual creativity, organisational learning and control as highlighted in the introduction. The research conducted in this paper makes an empirical contribution to the understanding of the implications of these cross-disciplinary requests for further research. It is suggested that further research could take an inductive approach for a new understanding of underlying specific issues important for subsequent projects providing a more specific and detailed contribution in subsequent projects.

The research conducted only integrates 4 ecosystem organizations as noted in the methods section. However, there is a need for integration of the whole offshore wind park energy ecosystem. This will require support from digitalization services according to the trinity approach of 'organization', 'BмI' and 'cashflow' for dissemination and cross- organizational and cross-disciplinary collaboration in the entire ecosystem to reduce LCoE. There is no open joint IT-platform available across ecosystem participants and only limited collaboration taking place at present ( Brink et al, 2015).

A limitation of the generalizability of the research findings can be foreseen. The same focused measure of LCoE is present in other renewable energy ecosystems and therefore some generalizability can be anticipated to e.g. onshore wind, solar energy and biogas. In Denmark the political majority neglected nuclear energy several decades ago and has since supported all kinds of renewable energy. It means that onshore energy now is on par with traditional 
energy sources for LCoE. However, offshore energy is producing more energy pr. wind turbine as wind conditions are better on Sea and therefore a better alternative than onshore wind causing inconvenience for inhabitants living near the onshore wind turbines.

Several measures of increased value proposition will often be present in an ecosystem (Kastelle and Steen, 2014) and therefore generalizability of the results can be limited. However, the 'one-measure-issue' of LCoE has the potential to sharpen the insights and reflections and thereby make it easier to understand and address the important issues. Further research in other ecosystems, such as waste-recycling and maritime transport systems is therefore needed to shed light on the generalizability of findings from this research.

\section{Conclusions}

The research conducted in this paper shows how port authorities in a triple helix context can contribute to strategic innovation to reduce LCoE in nearshore wind park ecosystems. The empirical qualitative case study was conducted from September 2017 to June 2018 in a port close to nearshore wind park sites in the Baltic Sea. The research started with individual interviews with the nearshore park owner, the nearby port and a logistic business actor operating on land and one operating at sea. These individual research meetings lasted approximately $3-5$ hours each and were conducted before the three collaborative action learning network meetings, the latter of which lasted approximately $6-7$ hours with two managers from each organization participating in the research.

The findings in this empirical research reveal that port authorities can enable strategic innovation for improvement of flow through the port, more secure interfaces between partners and development of a hub-port opportunity for the Baltic Sea with halved estimated investments in this triple helix context, through facilitation of the trinity of 'organization', 'BMI' and 'financial cash flow' on the project ecosystem level. The process containing this trinity shifts the interest of the participants from the interests of their own institutionalized organization to the interests of the ecosystem as shown in the result section. Opportunities for open, collaborative strategic innovation to achieve the joint aim of sustainability in society through the reduction of LCoE in the offshore wind energy ecosystem can then be shown. The gap in the time horizon between the long-term approach of port authorities and the predominantly short-term approach of the business enterprises is also addressed. The findings are summarized in a model for overview on the shift in interests in the triple 
helix frame. Additionally, the model stresses the need for an integrated understanding of flow and the available port spaces/equipment across time to enable strategic innovation. The implications from these findings highlight the importance of the shift of interests to the project ecosystem level.

A contribution is hereby made to the triple helix research field on the shift of interests to the project ecosystem level. A contribution is also made to the literature on cross-disciplinary insight and the understanding of the trinity containing 'organization', 'BMI' and 'financial cash-flow' literature to enable strategic innovation in the offshore wind park ecosystem context. Further research is needed to verify the findings and the generalizability of them.

\section{Acknowledgements}

The author would like to thank the participating enterprises having contributed anonymously to this article, the Danish Ministry of Higher Education and Science and the Innovation Network BrandBase for the financing of the research project. Additionally, the author would like to thank the anonymous reviewers for providing valuable input for the article.

Last but not least, the author would like to thank Associated Professor Erik Stavnsager Rasmussen and Student Assistant Thit Schmidt for their valuable collaboration during the research.

\section{References}

1. United Nations (UN), (2016). General Assembly - transforming our world: the 2030 Agenda for Sustainable Development. A/RES/70/1 link accessed 29. February 2016 - https://sustainabledevelopment.un.org/post2015/transformingourworld/ publication.

2. World Energy Council (WEC), (2017). World Energy Focus annual 2017. The energy transition: how innovation is driving change. Link assessed 16 September 2018: https://www.worldenergy.org/wp-content/uploads/2017/10/WEF-WEC_ Annual_2017_Web_LowRes.pdf.

3. Brink T, Madsen SO, Lutz S (2015). Perspectives on how Operation \& Maintenance (O\&M) innovations contribute to the reduction of levelized cost of energy (LCoE) in offshore wind parks. Danish Wind Industry Association - link: http://ipaper. ipapercms.dk/Windpower/OWDrapport.

4. Autio, E, Thomas, LDW (2014). Innovation Ecosystems - implications for innovation management?. In Dodgson, M., Cann, D.M. and Philips, N. (eds). The Oxford 
Handbook of Innovation Management. Chapter 11 pp. 204-228. Oxford University Press. Oxford.

5. Estate, Crown (2012). Offshore Wind Cost Reduction Pathways Study, viewed 2. Januaray 2015, http://www.thecrownestate.co.uk/media/5493/ei-offshore-windcost-reduction-pathways-study.pdf.

6. Radjou, N, Prabhu, J (2015). Frugal Innovation - How to do better with less. Profile Books: London.

7. Etzkowitz, H, Leydesdorff, L, (2000). The dynamics of innovation: from National Systems and "Mode 2" to a Triple Helix of university-industry-government relations. Research Policy 29, 109-14.

8. Leydesdorff, L, Meyer, M, (2006). Triple Helix indicators of knowledge-based innovation systems. Research Policy 35, 1441-8.

9. Coase RH (1937). The nature of the firm. Economica, vol. 4, No. 16; pp. 86-405.

10. Williamson, O.E. 1999. The Mechanisms of Governance. Oxford University Press. New York.

11. Laursen K, Salter AJ (2006). Open for Innovation: The Role of Openness in Explaining Innovation Performance Among UK Manufactoring Firms. Strategic Management Journal, vol. 27, no. 2; pp. 131-150.

12. Podolny JM, Page KL (1998). Network Forms of Organizations. Annual Review of Sociology. 24. No.1; pp. 57-76.

13. Brink T (2017). Organising for innovation in regional innovation systems: from fragmented innovation ecosystems to the joint aim for competiveness of offshore wind energy. Triple Helix Journal. Vol. 4, No. 1, pp. 1-18.

14. Grant RM (2016). Contemporary Strategy Analysis. Text and Cases. Ninth Edition. Wiley \& Sons: West Sussex, UK.

15. Hollen, R, (2015). Exploratory studies into strategies to enhance innovation-driven International port competiveness in a port context. Erasmus University Rotterdam. Link: https://repub.eur.nl/pub/78881.

16. de Langen, PW, Haezendonck, E, (2012). Ports as Clusters of Economic Activity. The Blackwell Companion to Maritime Economics, (February), pp. 638-655.

17. de Langen, PW, van der Lugt, LM, (2017). Institutional reforms of port authorities in the Netherlands; the establishment of port development companies. Research in Transportation Business \& Management, 22, pp. 108-113.

18. De Martino, M, Morvillo, A, (2008). Activities, resources and inter-organizational relationships: key factors in port competitiveness. Maritime Policy \& Management, 35(6), pp. 571-589.

19. De Martino, M, Carbone, V, Morvillo, A, (2015). Value creation in the port: opening the boundaries to the market. Maritime Policy \& Management, 42(7), pp. $682-698$.

20. Hollensen S (2016). Global Marketing. 7. Edition. Pearsson. 
21. Malhotra, Y, (2000). Knowledge management and new organization forms: a framework for business model innovation. Information Resources Management Journal, 13(1), pp. $5^{-14}$.

22. Schumpeter, JA, (1934). The Theory of Economic Development: An Inquiry Into Profits, Capital, Credit, Interest, and the Business Cycle, Transaction Books.

23. Zott, C, Amit, R, Massa, L, (2011). The business model: Recent developments and future research. Journal of Management, 37(4), pp. 1019-104.

24. Casadesus-Masanell, R, Zhu, F, (2013). Business Model Innovation and Competitive Imitation: The Case of Sponsor-based Business Models. Strategic Management Journal, 34, pp. 464-482.

25. Foss, NJ, Saebi, T, (2017). Fifteen Years of Research on Business Model Innovation: How Far Have We Come, and Where Should We Go? Journal of Management, 43(1), pp. 200-227.

26. Osterwalder, A, Pigneur, Y (2010). Business Model Generation. John Wiley \& Sons, Inc, Hoboken, New Jersey.

27. Schneider S, Spieth P (2013). Business model Innovation: Towards an integrated future research agenda. International Journal of Innovation Management, Vol. 17, No. 1., pp. 1-34.

28. Khanagha, S, Volberda, H, Oshri, I, (2014). Business model renewal and ambidexterity: Structural alteration and strategy formation process during transition to a Cloud business model. RD Management, 44(3), pp. 322-340.

29. Kashiwagi D, Byfield RE (2002). Selecting the best contractor to get performance: On time, on budget, meeting quality expectations. Journal of Facilities Management, Vol. 1 Issue 2, pp. 103-116.

30. Walker D, Lloyd Walker B (2016). Understanding the motivation and Context for alliancing in the Australian construction Industry. International Journal of Managing Projects in Business, vol. 9. No. 1, pp. 74-93.

31. Amabile TM, Conti R, Coon H, Lazenby J, Herron M (1996). Assessing the Work Environment for Creativity. Academy of Management Journal. Vol. 39, no. 5; pp. 1154-1184.

32. Brink T (2016). Organising to enable innovation. International Journal of Business and Innovation Research, vol. 10, No. 2/3, pp. 402-433.

33. Jung, CG (1968). Archetypes of the Collective Unconscious, in Read, H., Fordham, M., Adler, G., McGuire, W., (Eds) The Collected Works of Jung, Vol 9. Part 1, second edition reprinted 2009, Routledge, London, pp. 3-41.

34. Jacobi, J (1973). The Psychology of C.G. Jung. Yale University Press. New Haven and London.

35. Cameron, KS, Quinn, RE (2011). Diagnosing and Changing organizational Culture based on the competing values framework. Jossey-Bass - A Wiley Imprint, San Francisco, CA. 
36. Koller, T, Goedhart, M, Wessels, D, (2010). Valuation: Measuring and managing the value of companies. University Edition, Wiley Finance.

37. IRENA (2016). Global Atlas for Renewable Energy. International Renewable Energy Agency (IRENA), Accessed at link: http://irena.masdar.ac.ae.

38. Eisenhardt, KM (1989). Building Theories from Case study Research. The Academy Management Review, Vol. 14 No. 4, pp. 532-550.

39. Yin, RK (2009). Case Study Research. Design and Methods. Sage. Applied Social Research Methods and series; 5 .

40. Miles, MB, Huberman, AM, Saldana, J (2014). Qualitative dataanalysis - A Methods Sourcebook. $3^{\text {rd }}$. edition. Sage, Los Angeles, London, New Delhi, Singapore and Washington.

41. Benton S, Schurink C, Desson S (2008). An overview of the development, validity and reliability of the English version 3.0 of the Insights Discovery Evaluator. University of Westminster - link to PDF: http://insightscw.com/wp-content/uploads/2013/og/ExecutiveSummary-Validity-and-Reliability.pdf.Aug_.2008.pdf. - updated 2017 according to link: https://www.insights.com/what-we-do/validity/.

42. Kastelle T, Steen J (2014). Networks of innovation. In Dodgson, M, Gann D.M and Philips, N (eds). Innovation Management, chapter 6, pp. 102-120, Oxford, Oxford University Press.

43. Argyris C (1977). Double loop learning in Organizations. Harvard Business Review. 